\title{
Antigenotoxic properties of Paliurus spina- christi Mill fruits and their active compounds
}

\author{
Murat Zorr', Sevtap Aydin², Nadide Deniz Güner ${ }^{3}$, Nurşen Başaran² and Arif Ahmet Başaran*
}

\begin{abstract}
Background: Paliurus spina-christi Mill. (PS) fruits are widely used for different medical purposes in Turkey. Like in many medicinal herbs the studies concerning their activity, the activities of PS are also not well clarified. The aim of this study is to evaluate the antigenotoxicity of the compounds isolated and identified from the extracts of PS fruits.
\end{abstract}

Methods: The active compounds were separated, isolated, and determined by chromatographic methods and their structural elucidation was performed by Nuclear Magnetic Resonance (NMR) methods. The compounds were obtained from either ethyl acetate (EA) or n-butanol extracts. The cytotoxicities of the compounds using 3-(4,5-dimethylthiazol-2-yl)-2,5-diphenyltetrazolium bromide (MTT) assay and the antigenotoxic activities of the compounds using the alkaline single cell gel electrophoresis techniques (comet assay) were evaluated in Chinese hamster lung fibroblast (V79) cell lines.

Results: The isolated major compounds were identified as (+/-) catechins and gallocatechin from EA fraction and rutin from n-butanol fraction of PS fruits. Their chemical structures were identified by ${ }^{1} \mathrm{H}-\mathrm{NMR},{ }^{13} \mathrm{C}-\mathrm{NMR}, \mathrm{HMBC}$, and HMQC techniques. Half-maximal inhibitory concentration of catechins, gallocatechin, and rutin were found to be $734 \mu \mathrm{g} / \mathrm{mL}$, $220 \mu \mathrm{g} / \mathrm{mL}$, and $1004 \mu \mathrm{g} / \mathrm{mL}$, respectively. The methanolic extract of PS (1-100 $\mu \mathrm{g} / \mathrm{mL})$ alone did not induce DNA singlestrand breaks while catechins (1-100 $\mathrm{\mu g} / \mathrm{mL})$, gallocatechin $(1-50 \mu \mathrm{g} / \mathrm{mL})$, and rutin $(1-50 \mu \mathrm{g} / \mathrm{mL})$ significantly reduced $\mathrm{H}_{2} \mathrm{O}_{2}$-induced DNA damage.

Conclusion: It has been suggested that PS fruits and their compounds catechins, gallocatechin and rutin may have beneficial effects in oxidative DNA damage. It seems that PS fruits may be used in protection of the disorders related to DNA damage.

Keywords: Paliurus spina-christi Mill, Active compounds, Homo- and hetero-NMR, MTT assay, Comet assay, Chinese hamster lung fibroblast cells

\section{Background}

Medical treatments with herbs in Turkey having rich resources in terms of folk remedies are widely used. The arising interest of using natural compounds for health purposes has focused attention on plants having rich sources of bionutrient or bioactive phytochemicals. Many traditional usage of herbs are reviewed and their extracts or compounds are used in the treatment of some diseases such as cancer, cardiovascular disorders, diabetes, and

\footnotetext{
* Correspondence: abasaran@hacettepe.edu.tr

${ }^{4}$ Department of Pharmacognosy, Faculty of Pharmacy, Hacettepe University, 06100 Ankara, Turkey

Full list of author information is available at the end of the article
}

sepsis $[1,2]$. Reactive oxygen species (ROS) has an important role in the aetiology of several diseases. In general, phenolics are accepted as potentially scavengers of free radicals and their antioxidant capacities may vary due to their different chemical structures. The well known biological activity of catechins is their antioxidant and free radical scavenging properties. Catechins are dietary polyphenolic compounds associated with a wide variety of beneficial health effects in in vitro and in various animal models $[3,4]$. On the other hand, it is important to remember that under certain conditions, the phenolic structures, especially flavonoids, may undergo autooxidation and act as pro-oxidants as well [5]. 
Paliurus spina-christi Mill. (PS) (Rhamnaceae), also known as Christs thorn or Jerusalem thorn is found widely in Mediterranean region. PS fruits contain tannins, alkaloids, sterols, flavonoids such as rutin, isoquercetin, quercetin-3rutinoside-7-rhamnoside, kaempferol-3-glycoside and epigallocatechol, gallocatechol, catechol $[6,7]$. In our early study, quercetin, rutin, isoquercitrin, gallocatechin, (+) and (-) catechin, quercetin-3-O- $\alpha$-rhamnosyl $(1 \rightarrow 6)$ - $\beta$-galactoside, quercetin-3-O-[- $\beta$-xylosyl $(1 \rightarrow 2)$ - $\alpha$-rhamnozil $(1 \rightarrow 6)]$ $\beta$-glucoside, quercetin-3-O- $\alpha$-rhamnosyl $(1 \rightarrow 6)$ - $\beta$-galactoside-7-O- $\alpha$-rhamnoside were isolated from dried PS fruits [8].

PS is traditionally used as diuretic, antirheumatic, hypocholesterolemic and tonic as well as in inflammation, diarrhea, and chronic obstructive pulmonary disease [7]. Its water extract and their compounds show antimicrobial, antibacterial, antifungal, hypolipidemic and antioxidant activities [9-11]. Tsarubol was isolated from the whole fruit of PS and its therapeutic efficacy on chronic hepatocholecystitis was demonstrated by Kemertelidze et al. [12]. To continue our studies on the evaluation of the protective effects of the medicinal plants on genotoxicity by comet assay [13-15], we decided to examine the effects of PS extract also. Being a sensitive, rapid, simple and multidirectional method, comet assay is getting popular in determining antigenotoxicity of herbal extracts in vitro and also known as single cell gel electrophoresis assay. The method was found by Ostling and Johanson [16] developed by Singh et al. [17], and used for the measuring DNA strand breaks in eukaryotic cells at single cell level $[18,19]$. The previous in vitro and in vivo studies, showed the protective effects of some phenolic compounds on oxidative DNA damage by comet assay [20-33].

With this study, the chemical structures of the major active compounds of PS fruits were elucidated by NMR methods and named as catechins, gallocatechin and rutin. Their cytotoxic effects were determined in Chinese hamster lung fibroblast (V79) cell lines. Then, the protective effects of the compounds against $\mathrm{H}_{2} \mathrm{O}_{2}$-induced DNA damage were investigated by comet assay in vitro.

\section{Methods \\ Materials}

The chemicals used in the experiments were purchased from the following suppliers: Fetal calf serum (FCS), trypsin-EDTA, RPMI 1640, penicillinstreptomycin, L-glutamine from Biological Industries (Kibbutz Beit-Haemek, Israel); low melting point agarose (LMA), 3-(4,5-dimethylthiazol-2-yl)-2,5-diphenyltetrazolium bromide (MTT) dye, methylene blue dye, and normal melting point agarose (NMA) from Boehringer Mannheim (Mannheim, Germany); acetic acid, acetone, n-butanol, n-butanon, EA, formic acid, n-hekzan, chloroform $\left(\mathrm{CHCl}_{3}\right)$, methanol $(\mathrm{MEOH})$, sodium chloride $(\mathrm{NaCl})$, sodium hydroxide $(\mathrm{NaOH})$, sulphuric acid, toluen from Merck Chemicals (Darmstadt, Germany); dimethyl sulfoxide (DMSO), ethanol, ethidium bromide (EtBr), methanol, phosphate buffered saline (PBS) from Sigma (St. Louis, MO, USA); ethylenediamine tetra acetic acid disodium salt dihydrate ( $\mathrm{Na}_{2}$-EDTA), N-lauroyl sarcosinate, tris, and Triton X-100 from ICN Biomedicals Inc. (Aurora, Ohio, USA). Water $\left(\mathrm{H}_{2} \mathrm{O}\right)$ was supplied from in a Milli-Q (Millipore, Bedford, MA, USA) water purification system.

\section{Preparation of plant extracts}

Paliurus spina-christi Mill. (PS) was identified by the Department of Pharmaceutical Botany of Hacettepe University and the voucher specimens (HUEF 99-078 and HUEF14-078) were deposited at the herbarium of the Faculty of Pharmacy, Hacettepe University, Turkey.

PS fruits were collected from Kastamonu region of Turkey in July 2014 and kept in air-dried room temperature $\left(20 \pm 2{ }^{\circ} \mathrm{C}\right)$. Air dried fruits (300 g) were powdered using a mechanical grinder and extracted with $1000 \mathrm{~mL}$ of $\mathrm{MeOH}: \mathrm{H}_{2} \mathrm{O}(70: 30 \mathrm{v} / \mathrm{v})$ in $40{ }^{\circ} \mathrm{C}$ in a continuous extractor for $48 \mathrm{~h}$. The extract was then concentrated at $40{ }^{\circ} \mathrm{C}$ using a rotary evaporator (Büchi RE 111, Büchi EL 131, Flawil, Switzerland) and used for the phytochemical investigations. The extract was pre-fractionated with n-hexane, EA, and n-butanol, respectively.

\section{Phytochemical studies of the PS extracts}

The EA fraction (1.1 g) and the n-butanol fraction (8.5 g) were first investigated by TLC (thin layer chromatography). The fractions rich in phenolics were applied to a polyamide chromatography separately using a gradient system of $\mathrm{MeOH}$ and $\mathrm{H}_{2} \mathrm{O}$ from 0 to100. Following the fractions rich in phenolics were applied to column chromatography method using silicagel (Kieselgel 60,70-230 mesh) with the elution system $\mathrm{CHCl}_{3}: \mathrm{MeOH}$ (90:10 to $25: 75 v / v)$. The lyophilization of these fractions was performed by a lyophilizer (VirTis Freezemobile 6, SP Scientific, NY, USA). The isolation of (-) catechin $(2.33 \mathrm{mg}$ ) from EA fraction were carried out in Sephadex LH20 column using MeOH. A fraction from the same sephadex LH20 column was first applied to silicagel (Kieselgel 60,70-230 mesh) column with the elution system EA:Formic acid:Acetic acid: $\mathrm{H}_{2} \mathrm{O}$ (100:11:11:27). Gallocatechin $(5.63 \mathrm{mg}$ ) and $(+)$ catechin $(3.61 \mathrm{mg})$ were isolated and purified by preparative TLC (Kieselgel 60) using the solvent system $\mathrm{CHCl}_{3}: \mathrm{MeOH}: \mathrm{H}_{2} \mathrm{O}$ (61:32:7). Rutin was isolated from polyamide column after elution with methanol:water (50:50) and purified by precipitation. 
The structure elucidations of the compounds were performed by homo and hetero Nuclear Magnetic Resonance (NMR) techniques $\left({ }^{1} \mathrm{H}-\mathrm{NMR} 600 \mathrm{MHz}, \mathrm{CD}_{3} \mathrm{OD} ;{ }^{13} \mathrm{C}-\mathrm{NMR}\right.$ $150 \mathrm{MHz}, \mathrm{CD}_{3} \mathrm{OD}$ : Jeol Ecp-600 FT-NMR, MA USA).

The concentrations of the compounds were increased using the same systems to use in biological experiments. $(+)$ and $(-)$ Catechins were used together in the experiments.

\section{Cell culture}

V79 cells were purchased from American Type Culture Collection (Manassas, VA, USA). The cells were maintained and grown as a monolayer in culture plastic flasks $\left(75 \mathrm{~cm}^{2}\right)$. The culture medium was RPMI 1640 medium with L-glutamine, containing $10 \%$ heat-inactivated fetal bovine serum, $100 \mathrm{U} / \mathrm{L}$ penicillin, and $100 \mu \mathrm{g} / \mathrm{mL}$ streptomycin. The cells were kept in a incubator (Thermo Scientific Heraeus, Germany) at $37 \pm 1{ }^{\circ} \mathrm{C}$ with a humidified atmosphere of $95 \%$ air and $5 \% \mathrm{CO}_{2}$. The culture medium was renewed every 3 days. V79 cells used in all experiments were between the 3rd and 5th culture passage after thawing.

\section{Determination of cytotoxicity}

The proliferative or cytotoxic effects of PS extracts were determined using MTT assay, first described by Mosmann [34] with the modification of Denizot and Lang [35]. V79 cell line was chosen because of its high sensitivity to various chemicals with excellent properties in colony formation. These adherent cells are very convenient practically in MTT assay. After growing for 2 weeks, V79 cells were seeded at a density of 5000 cells/well in a 96-well plate and allowed to grow for $24 \mathrm{~h}$ before treatment. The cells were treated with each compounds at different concentrations $(0,1,5,10,25,50$, $100,250,500,1000$, and $2000 \mu \mathrm{g} / \mathrm{mL}$ ) in the culture medium for $24 \mathrm{~h}$. The compounds were dissolved in DMSO and added to the medium to yield a final DMSO concentration of $0.5 \%(v / v)$. Control experiments were carried out with the culture medium containing $0.5 \%$ of DMSO without PS extracts. Later the medium was removed and $0.5 \mathrm{mg} / \mathrm{mL}$ MTT solution in $100 \mu \mathrm{L}$ of the culture medium was added to each well and further incubated at $37^{\circ} \mathrm{C}$. medium was discarded after $4 \mathrm{~h}$, and $100 \mu \mathrm{L}$ of PBS was added to wash the cells. After removing PBS, $100 \mu \mathrm{L}$ of DMSO was added to dissolve the formazan crystals at $37{ }^{\circ} \mathrm{C}$ for $10 \mathrm{~min}$. Absorbance of each sample was measured at $570 \mathrm{~nm}$ using the microplate reader (SpectraMax M2, Molecular Devices Limited, Berkshire, UK). Cytotoxicity was determined by the percentage of the ratio between treated and untreated (control) cells (\% cell viability) using Eq. (1). $A_{\text {blank }}$ and $\mathrm{A}_{\text {sample }} /$ control indicate the absorbance of blank and
Table 1 Spectral determination of (+/-) catechins in ${ }^{1} \mathrm{H}-\mathrm{NMR}$ and ${ }^{13} \mathrm{C}-\mathrm{NMR}^{\mathrm{a}}$

\begin{tabular}{lllll}
\hline Atom C/H & $\delta_{\mathrm{H}}(\mathrm{ppm})$ & $\mathrm{J}(\mathrm{Hz})$ & $\delta_{\mathrm{C}}(\mathrm{ppm})$ & $\mathrm{HMBC}(\mathrm{H} \rightarrow \mathrm{C})$ \\
\hline 2 & $4.55 \mathrm{~d}$ & 7.4 & 82.88 & $\mathrm{C}-4, \mathrm{C}-3, \mathrm{C}-9$ \\
3 & $3.96 \mathrm{ddd}$ & $5.5 / 7.5 / 8.1$ & 68.83 & $\mathrm{C}-10$ \\
4 & $(\alpha) 2.84 \mathrm{dd}$ & $15.9 / 5.5$ & 28.54 & $\mathrm{C}-2, \mathrm{C}-3, \mathrm{C}-9, \mathrm{C}-10$ \\
& $(\beta) 2.84 \mathrm{dd}$ & $15.9 / 8.0$ & & \\
5 & - & - & 156.92 & \\
6 & $5.84 \mathrm{~d}$ & 2.2 & 95.51 & $\mathrm{C}-8, \mathrm{C}-10$ \\
7 & - & - & 157.59 & \\
8 & $5.91 \mathrm{~d}$ & 2.2 & 96.30 & $\mathrm{C}-6, \mathrm{C}-10$ \\
9 & - & - & 157.86 & \\
10 & - & - & 100.83 & \\
$1^{\prime}$ & - & - & 132.35 & \\
$2^{\prime}$ & $6.82 \mathrm{~d}$ & 1.9 & 115.27 & $\mathrm{C}-1^{\prime}, \mathrm{C}-2$ \\
$3^{\prime}$ & - & - & 146.23 & \\
$4^{\prime}$ & - & - & 146.23 & \\
$5^{\prime}$ & $6.75 \mathrm{~d}$ & 8.2 & 116.08 & $\mathrm{C}-1^{\prime}$ \\
$6^{\prime}$ & $6.70 \mathrm{dd}$ & $8.2 / 1.9$ & 120.03 & $\mathrm{C}-2$ \\
\hline
\end{tabular}

${ }^{\mathrm{a} 1} \mathrm{H}-\mathrm{NMR}: 600 \mathrm{MHz}, \mathrm{CD}_{3} \mathrm{OD} ;{ }^{13} \mathrm{C}-\mathrm{NMR}: 150 \mathrm{MHz}, \mathrm{CD}_{3} \mathrm{OD}$

absorbances of samples or control, respectively. $\mathrm{IC}_{50}$ values of the compounds, the concentration reducing the cell viability of treated cells by $50 \%$ with reference to the control (untreated cells), were determined from the dose-response curves. Four independent assays were performed.

Table 2 Spectral determination of (-)-gallocatechin in ${ }^{1} \mathrm{H}-\mathrm{NMR}$ and ${ }^{13} \mathrm{C}-\mathrm{NMR}^{\mathrm{a}}$

\begin{tabular}{lllll}
\hline Atom C/H & $\delta_{\mathrm{H}}(\mathrm{ppm})$ & $\mathrm{J}(\mathrm{Hz})$ & $\delta_{\mathrm{C}}(\mathrm{ppm})$ & $\mathrm{HMBC}(\mathrm{H} \rightarrow \mathrm{C})$ \\
\hline 2 & $4.51 \mathrm{~d}$ & 7.2 & 82.89 & $\mathrm{C}-4, \mathrm{C}-1^{\prime}$ \\
3 & $3.95 \mathrm{~m}$ & - & 68.78 & $\mathrm{C}-4, \mathrm{C}-10$ \\
4 & $(\alpha) 2.80 \mathrm{dd}$ & $16.2 / 5.5$ & 28.13 & $\mathrm{C}-10$ \\
& $(\beta) 2.48 \mathrm{dd}$ & $16.2 / 7.7$ & & \\
5 & - & - & 156.85 & \\
6 & $5.84 \mathrm{~d}$ & 2.2 & 95.53 & $\mathrm{C}-8, \mathrm{C}-10$ \\
7 & - & - & 157.60 & \\
8 & $5.91 \mathrm{~d}$ & 2.2 & 96.28 & $\mathrm{C}-6, \mathrm{C}-10$ \\
9 & - & - & 157.84 & \\
10 & - & - & 100.73 & \\
$1^{\prime}$ & - & - & 131.60 & \\
$2^{\prime}$ & $6.39 \mathrm{~s}$ & - & 107.20 & $\mathrm{C}-2, \mathrm{C}-6^{\prime}$ \\
$3^{\prime}$ & - & - & 146.87 & \\
$4^{\prime}$ & - & - & 134.01 & \\
$5^{\prime}$ & - & - & 146.87 & \\
$6^{\prime}$ & $6.39 \mathrm{~s}$ & - & 107.20 & $\mathrm{C}-2, \mathrm{C}-2^{\prime}$ \\
\hline
\end{tabular}

${ }^{\mathrm{a}} \mathrm{H}-\mathrm{NMR}: 600 \mathrm{MHz}, \mathrm{CD}_{3} \mathrm{OD} ;{ }^{13} \mathrm{C}-\mathrm{NMR}: 150 \mathrm{MHz}, \mathrm{CD}_{3} \mathrm{OD}$ 


$$
\begin{aligned}
& \text { Percentage of cell viability (\%cell viability }) \\
& =\left(\mathrm{A}_{\text {samples }}-\mathrm{A}_{\text {blank }}\right) /\left(\mathrm{A}_{\text {control }}-\mathrm{A}_{\text {blank }}\right) \times 100
\end{aligned}
$$

\section{Determination of genotoxicity and antigenotoxicity}

We determined the genotoxic or antigenotoxic effects of the samples at the concentration of less than $\mathrm{IC}_{50}$ by alkaline comet assay in V79 cells. The alkaline comet assay was carried out to analyze DNA single strand breaks as described by Tice et al. [36] with minor modifications. V79 cells were harvested by treatment with $0.15 \%$ trypsin- $0.18 \%$ EDTA in the medium without FBS. Then the cells were seeded $\left(25 \times 10^{3}\right.$ cells $)$ in $2 \mathrm{~mL}$ of the culture medium in a six-well plate and grown for $24 \mathrm{~h}$ up to $60-70 \%$ confluence before treatment with the compounds in the incubator. The cells were incubated with the compounds at non-cytotoxic concentrations $(1,5,25,50$, and $100 \mu \mathrm{g} / \mathrm{mL})$ in the culture medium for
$1 \mathrm{~h}$. Final DMSO concentration in the medium never exceeded $0.5 \%$. After pretreatment of the compounds for $1 \mathrm{~h}$, oxidative DNA damage was induced by replacing the medium with PBS containing $100 \mu \mathrm{M} \mathrm{H}_{2} \mathrm{O}_{2}$ and then the cells were incubating for 5 min to assess the antigenotoxicity of the compounds. Then the cells were harvested by treatment with $0.15 \%$ trypsin- $0.18 \%$ EDTA in the medium without FBS, centrifuged, and washed with $\mathrm{PBS}$ for removing the $\mathrm{H}_{2} \mathrm{O}_{2}$ solution. A negative control (0.5\% DMSO) and positive control $100 \mu \mathrm{M} \mathrm{H}_{2} \mathrm{O}_{2}$ were also included in the experiment. After centrifugation at $1100 \mathrm{rpm}$, supernatant was discarded. $1 \times 10^{4}$ cells in $50 \mu \mathrm{L}$ PBS were suspended in $100 \mu \mathrm{L}$ of $0.65 \%$ LMA. Then the suspensions were embedded on the slides pre-coated with a layer of $1 \%$ NMA. The slides were allowed to solidify on ice for $5 \mathrm{~min}$. Coverslips were then removed. The slides were immersed in cold lysing solution $(2.5 \mathrm{M} \mathrm{NaCl}, 100 \mathrm{mM}$ EDTA, $100 \mathrm{mM}$ Tris, 1\% sodium sarcosinate, $\mathrm{pH} 10.0$ ), with $1 \%$ Triton X-100 and 10\% DMSO added just

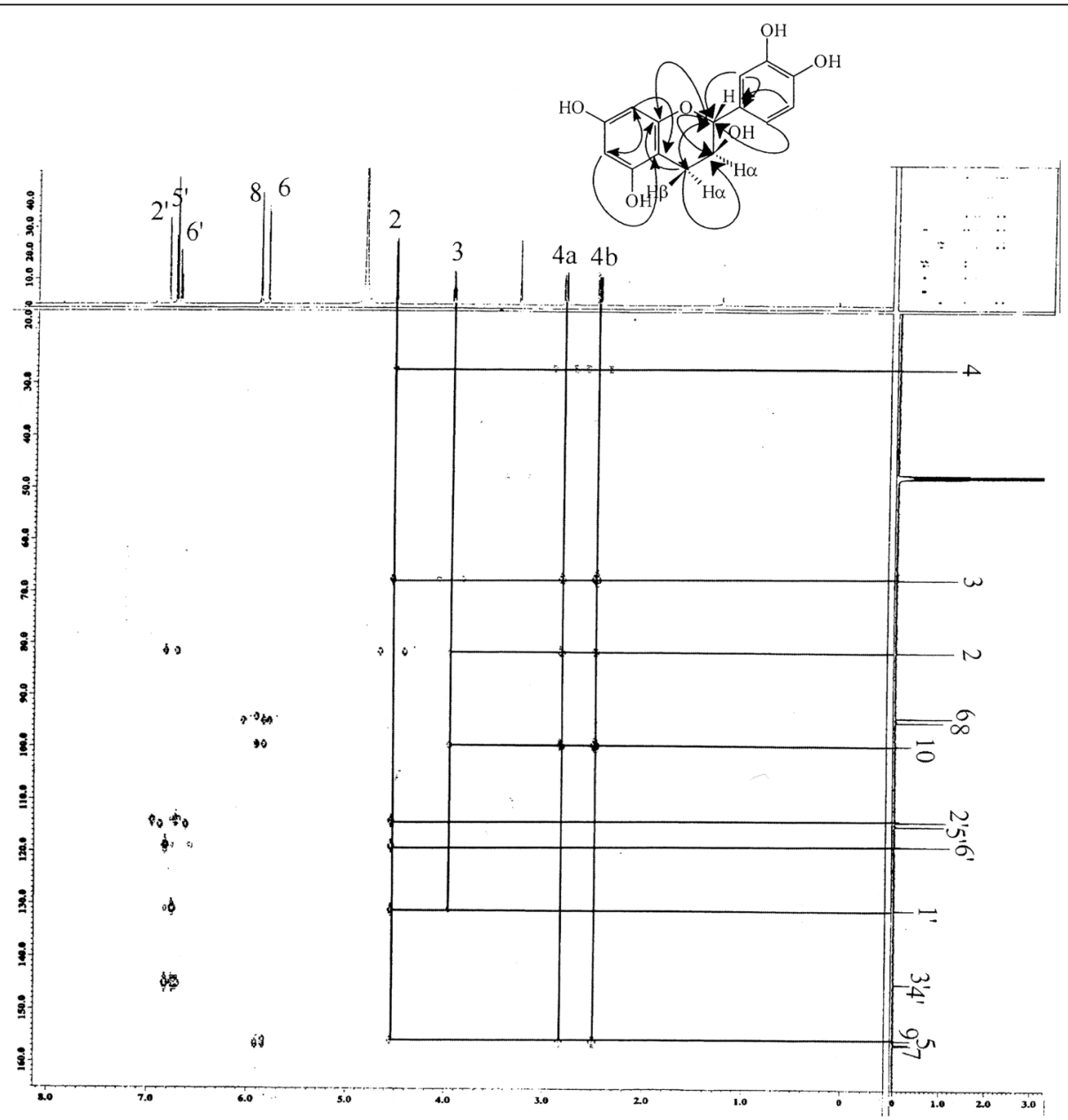

Fig. $1 \mathrm{HMBC}$ spectrums of $(+,-)$ catechin 
before use for $3 \mathrm{~h}$ at $4{ }^{\circ} \mathrm{C}$. Then they were removed from the lysing solution, drained and were left in the electrophoresis solution $(1 \mathrm{mM}$ sodium EDTA and $300 \mathrm{mM} \mathrm{NaOH}, \mathrm{pH} 13.0$ ) for $20 \mathrm{~min}$ at $4{ }^{\circ} \mathrm{C}$ to allow for unwinding of the DNA and expression of alkalilabile damage. Electrophoresis was conducted also at a low temperature $\left(4{ }^{\circ} \mathrm{C}\right)$ for 20 min using $25 \mathrm{~V}$ with a current of $300 \mathrm{~mA}$. The slides were neutralized by washing 3 times in $0.4 \mathrm{M}$ Tris- $\mathrm{HCl}(\mathrm{pH} \mathrm{7.5)}$ for $5 \mathrm{~min}$ at room temperature. After neutralization, the slides were incubated in $50 \%, 75 \%$, and $99 \%$ of alcohol for 5 min, successively. The dried microscope slides were stained with EtBr $\left(20 \mu \mathrm{g} / \mathrm{mL}\right.$ in distilled $\mathrm{H}_{2} \mathrm{O}, 35 \mu \mathrm{L} /$ slide), covered with a cover-glass prior to analysis with a fluorescence microscope (Leica Microsystems $\mathrm{GmbH}$, Wetzlar, Germany) under green light. The microscope was connected to a charge-coupled device camera and a personal computer-based analysis system (Comet Analysis Software, version 3.0, Kinetic Imaging Ltd., Liverpool, UK) to determine the extent of DNA damage after electrophoretic migration of the DNA fragments in the agarose gel. In order to visualize DNA damage, slides were examined at $40 \times$. The experiment was repeated four times. One-hundred cells from two replicate slides were assayed for each experiment. DNA damage was expressed as the product of the tail length and the fraction of total DNA in the tail "DNA tail moment".

\section{Statistical analysis}

The statistical analysis was performed using the software programs SPSS 15.0 (SPSS, Chicago, IL, USA). The distribution of the data was checked for normality using the Shapiro-Wilk test. The homogeneity of the variance was verified by the Levene test. Differences between the means of data were compared by the one way variance analysis test and post hoc analysis of group differences was performed by least significant difference test. The results were given as the mean \pm standard

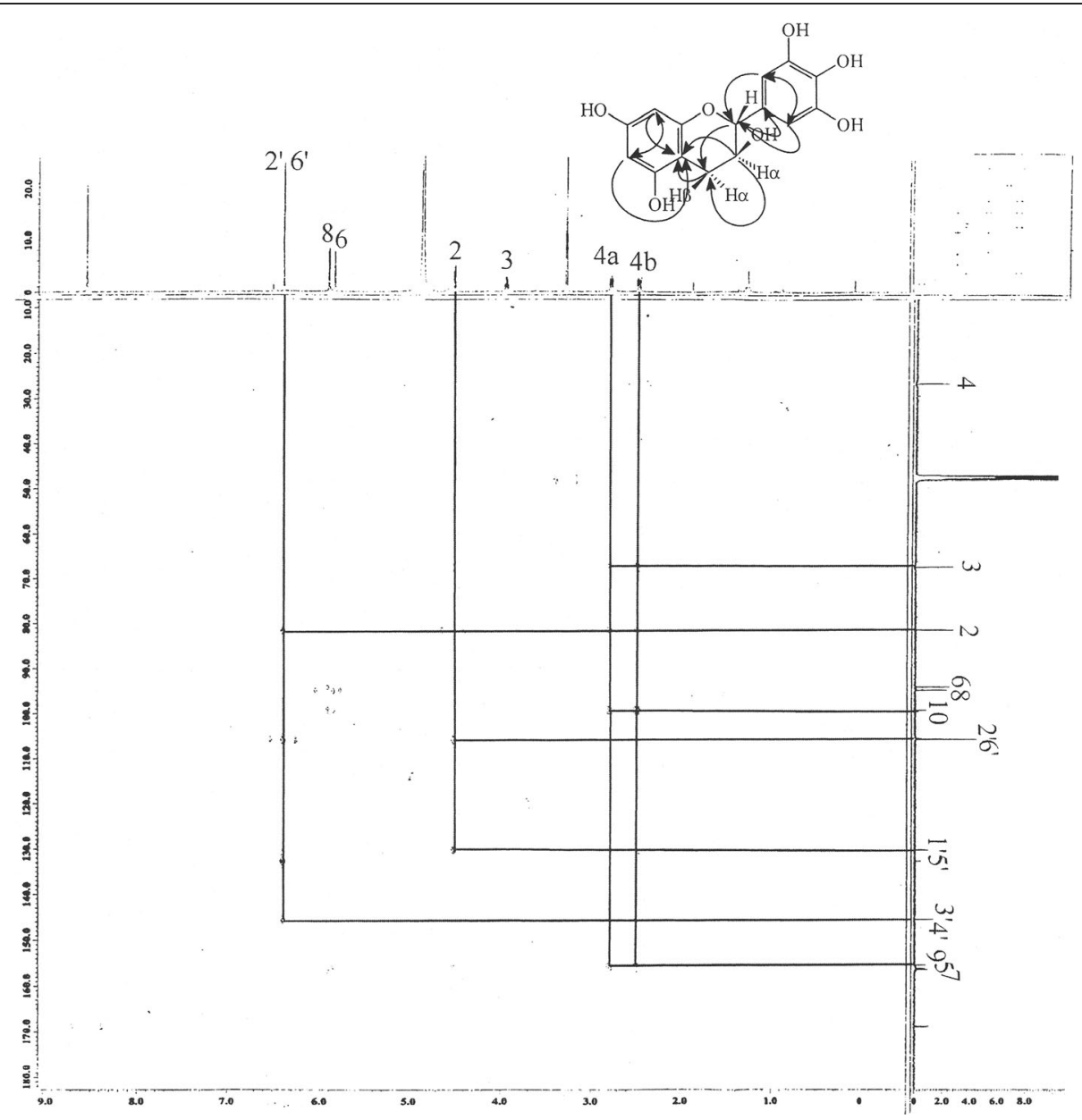

Fig. $2 \mathrm{HMBC}$ spectrums of (-)-gallocatechin 
deviation. $P$ value of less than 0.05 was considered as statistically significant.

\section{Results and discussion}

Determination of phytochemical constituents of PS extracts

The compounds $(+),(-)$ catechins and gallocatechin were isolated from EA fraction by chromatographic methods as done previously [8]. The chemical elucidation of the isolated compounds was identified by ${ }^{1} \mathrm{H}$ - and ${ }^{13} \mathrm{C}$-NMR method (Tables 1 and 2 ). The interpretation of the proton signals was realized by the spectrum of $2 \mathrm{D}^{-}{ }^{1} \mathrm{H}-{ }^{1} \mathrm{H}$ homo and heteronuclear correlation (COSY) and the shared spin systems show the presence of the protons of phenyl ring with other protons, where the results were in good accordance with references. Carbon signals with short distance proton signals, methylene signals, 2 non substitute methine groups and other signals supported both catechin and gallocatechin skeleton in the HMQC spectrum. HMBC spectrum of gallocatechin showed interactions with the protons especially the long distance interactions of $\mathrm{H}-2$ proton with $\mathrm{C}-1^{\prime}$ and protons of $\mathrm{H}-3 ; \mathrm{H}-4 ; \mathrm{H}-6$ and $\mathrm{H}-8$ with $\mathrm{C}-10$ confirms the skeleton (Fig. 1). The confirmation of the catechin structure obtained from the long term interactions of protons $\mathrm{H}-2$ and $\mathrm{H}-5$ with $\mathrm{C}-1^{\prime}$ and $\mathrm{H}-3, \mathrm{H}-4, \mathrm{H}-6$, and $\mathrm{H}-8$ with $\mathrm{C}-10$ with the correlated NMR techniques was also shown in Fig. 2. The major compound of n-butanol fraction was identified as rutin, a flavonoid glycoside, from the data obtained by ${ }^{1} \mathrm{H}$ - and ${ }^{13} \mathrm{C}$-NMR analysis showing the chemical structure clearly (Table 3 ).

The spectral data of the compounds were also confirmed as $(+)(-)$ catechin, gallocatechin, and rutin by comparing with authentic samples and literature data [37-42].

\section{Cytotoxicity of catechins, gallocatechin, and rutin}

The cytotoxic effects of the compounds in wide concentration ranges in V79 cells were shown in Fig. 3a, b, and c. Catechins and rutin significantly increased the cell proliferation at the concentrations of $1 \mu \mathrm{g} / \mathrm{mL}$ and $5 \mu \mathrm{g} / \mathrm{mL}$, respectively, for $24 \mathrm{~h}$. The cell viabilities started to decline at the higher concentrations of $250 \mu \mathrm{g} / \mathrm{mL}, 25 \mu \mathrm{g} / \mathrm{mL}$, and $500 \mu \mathrm{g} / \mathrm{mL}$, respectively for catechins, gallocatechin and rutin. According to the results, catechins, gallocatechin, and rutin significantly decreased the cell viability at the concentrations of $500 \mu \mathrm{g} / \mathrm{mL}, 50 \mu \mathrm{g} / \mathrm{mL}$, and $1000 \mu \mathrm{g} / \mathrm{mL}$, respectively $(p<0.05)$. The concentration-dependent cytotoxicity was observed in V79 cells after $24 \mathrm{~h}$ exposure for catechins, gallocatechin, and rutin. The $\mathrm{IC}_{50}$ values of catechins, gallocatechin, and rutin in V79 cells were found to be $734 \mu \mathrm{g} / \mathrm{mL}, 220 \mu \mathrm{g} / \mathrm{mL}$, and $1004 \mu \mathrm{g} / \mathrm{mL}$, respectively. According to the $\mathrm{IC}_{50}$ values of the compounds, the rank order of cell growth inhibitory potency in V79 cells was arranged as gallocatechin $>$ catechins $>$ rutin.

Catechins significantly increased cell proliferation at the concentrations of $1 \mu \mathrm{g} / \mathrm{mL}$ and $5 \mu \mathrm{g} / \mathrm{mL}$, resulting in $15.6 \%$ and $20.5 \%$ increase upon control, respectively $(p<0.05)$ (Fig. 3a). Rutin also increased the cell proliferation at the concentrations of $1 \mu \mathrm{g} / \mathrm{mL}$ and $5 \mu \mathrm{g} / \mathrm{mL}$ significantly, resulting in $34.7 \%$ and $22.6 \%$ upon control, respectively $(p<0.05)$ (Fig. 3c).

As there are limited studies on the toxicities of catechins, gallocatechin, and rutin, we examined the cytotoxic potencies of the compound as mentioned above in V79 cells. Our results showed that catechin,

\begin{tabular}{clll}
\multicolumn{4}{c}{ Table 3 Spectral determination of rutin in ${ }^{1} \mathrm{H}-\mathrm{NMR}$ and ${ }^{13} \mathrm{C}-\mathrm{NMR}{ }^{\mathrm{a}}$} \\
\hline Atom C/H & $\delta_{\mathrm{H}}(\mathrm{ppm})$ & $\mathrm{J}(\mathrm{Hz})$ & $\delta_{\mathrm{C}}(\mathrm{ppm})$ \\
\hline 2 & - & - & 82.89 \\
3 & - & - & 68.78 \\
4 & - & - & 28.13 \\
5 & - & 1.8 & 156.85 \\
6 & $6.19 \mathrm{~d}$ & - & 95.53 \\
7 & - & 2.4 & 157.60 \\
8 & $6.38 \mathrm{~d}$ & - & 96.28 \\
9 & - & - & 157.84 \\
10 & - & - & 100.73 \\
$1^{\prime}$ & - & 1.8 & 131.60 \\
$2^{\prime}$ & $7.66 \mathrm{~d}$ & - & 107.20 \\
$3^{\prime}$ & - & - & 146.87 \\
$4^{\prime}$ & - & 8.5 & 134.01 \\
$5^{\prime}$ & $6.86 \mathrm{~d}$ & $8.5 / 1.8$ & 146.87 \\
$6^{\prime}$ & $7.64 \mathrm{dd}$ & & 107.20
\end{tabular}

$\begin{array}{clll}\begin{array}{c}\text { B-Glucose } \\ \text { 1" }\end{array} & 5.10 \mathrm{~d} & 7.9 & 104.8 \\ 2^{\prime \prime} & 3.46 \mathrm{dd} & 9.8 / 7.5 & 75.7 \\ 3^{\prime \prime} & 3.25 \mathrm{t} & 9.8 & 78.1 \\ 4^{\prime \prime} & 3.29 \phi & \phi & 71.4 \\ 5^{\prime \prime} & 3.38 \mathrm{~m} & & 77.1 \\ 6 " \mathrm{a} & 3.79 \mathrm{dd} & 11.0 / 1.2 & 68.6 \\ 6 " \mathrm{~b} & 3.63 \mathrm{dd} & 12.0 / 4.9 & \end{array}$

$\begin{array}{clll}\alpha \text {-rhamnose } & & & \\ 1^{\prime \prime} & 4.51 \mathrm{~d} & 1.8 & 102.4 \\ 2^{\prime \prime} & 3.63 \mathrm{dd} & 3.7 / 1.8 & 72.1 \\ 3^{\prime \prime} & 3.53 \mathrm{dd} & 9.8 / 3.7 & 72.2 \\ 4^{\prime \prime} & 3.28 \mathrm{t} & 9.8 & 73.9 \\ 5^{\prime \prime} & 3.43 \mathrm{~m} & - & 69.7 \\ 6^{\prime \prime} & 1.12 \mathrm{~d} & 6.7 & 17.9\end{array}$

${ }^{a 1} \mathrm{H}-\mathrm{NMR}: 600 \mathrm{MHz}, \mathrm{CD}_{3} \mathrm{OD} ;{ }^{13} \mathrm{C}-\mathrm{NMR}: 150 \mathrm{MHz}, \mathrm{CD}_{3} \mathrm{OD}$ $\phi$ : non calculated because of interference 
gallocatechin, and rutin significantly decreased the cell viability at the concentrations of $250 \mu \mathrm{g} / \mathrm{mL}, 50 \mu \mathrm{g} / \mathrm{mL}$, and $500 \mu \mathrm{g} / \mathrm{mL}$, respectively, in a concentration dependant manner.

Catechin was found as inhibitor in the growth of human liver carcinoma cell line (HepG2) cell lines at the concentrations of $100-200 \mu \mathrm{g} / \mathrm{mL}$ [43]. Significant decrease in cell viability was observed on V79 cells when treated with $\mathrm{H}_{2} \mathrm{O}_{2}(1 \mathrm{mM})$, while herbal extracts and its flavonoids and (-)-epigallocatechin-3-gallate (EGCG) prevented the lactate lactate dehydrogenase release from $\mathrm{H}_{2} \mathrm{O}_{2}$ cytotoxicity [44]. Total catechin content of green tea was reported to be $65.6 \mathrm{mg} / \mathrm{g}$ of dry matter and the green tea exhibited the lowest $\mathrm{IC}_{50}$ values $(2 \mathrm{~g}$ fresh herb/100 mL) [44]. Cytotoxic effects of rutin for $48 \mathrm{~h}$ incubation in HL-60 leukemic cells were determined by MTT test. The $\mathrm{IC}_{50}$ values of rutin were about $14 \mathrm{mg} / \mathrm{mL}$ and the concentration-dependent cytotoxic effect of rutin was demonstrated [45]. In human leukaemia K562 cell lines (K562 cells), $\mathrm{IC}_{50}$ of rutin was found to be $400 \mu \mathrm{g} / \mathrm{mL}$ for $24 \mathrm{~h}$ and a dose dependant inhibition of cell viability

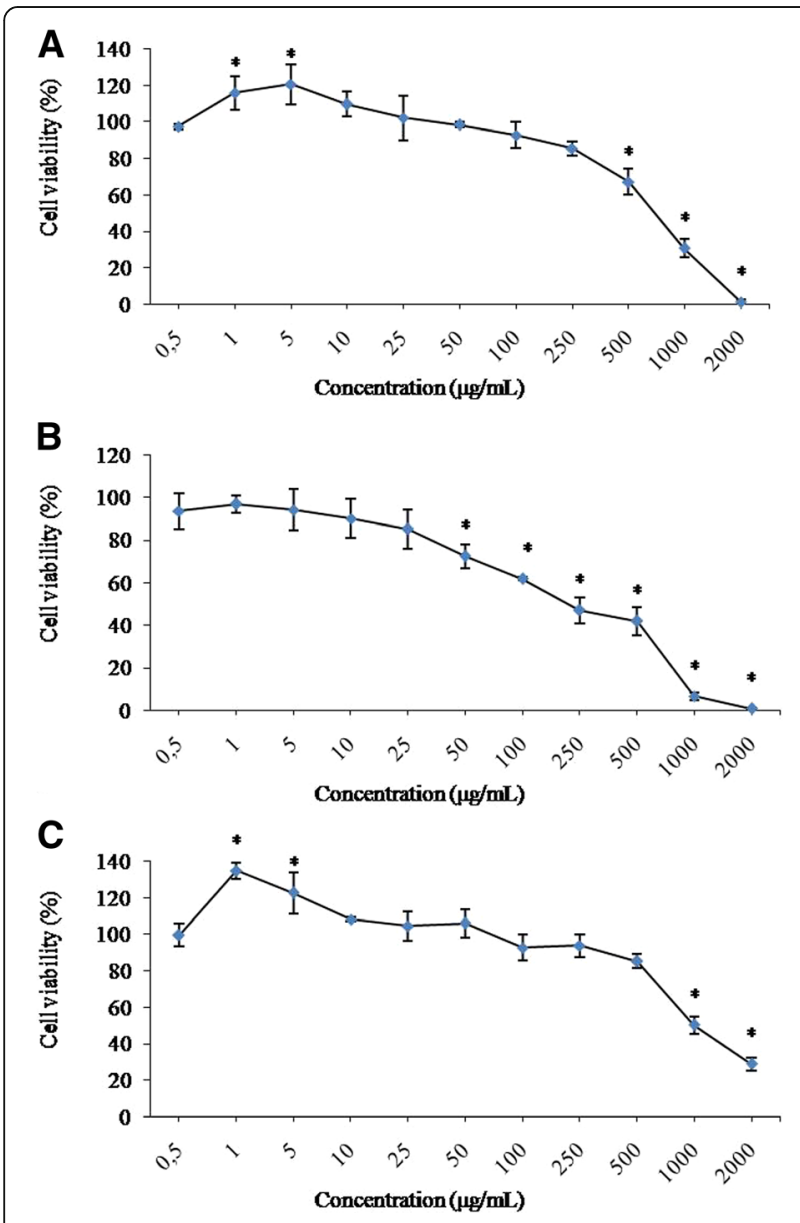

Fig. 3 Cytotoxicity of (+/-) catechins (a), gallocatechin (b) and rutin (c) in V79 cells. ${ }^{*} p<0.05$, compared with negative control (0.5\% DMSO) was reported [46]. Rutin above the concentrations higher than $50 \mu \mathrm{g} / \mathrm{mL}$ exhibited a cytotoxic effect in HepG2 cells for $24 \mathrm{~h}$ treatment [47].

\section{Antigenotoxicity of catechins, gallocatechin, and rutin}

The results of the genotoxicity and antigenotoxicity of PS extracts in V79 cells using alkaline comet assay were shown in Figs. 4 and 5.

$1-100 \mu \mathrm{g} / \mathrm{mL}$ of $(+)$ and $(-)$ catechin fraction significantly decreased $\mathrm{H}_{2} \mathrm{O}_{2}$-induced DNA damage $(p<0.05)$. A dose dependent protective effects in the concentrations of $1 \mu \mathrm{g} / \mathrm{mL}, 5 \mu \mathrm{g} / \mathrm{mL}, 25 \mu \mathrm{g} / \mathrm{mL}, 50 \mu \mathrm{g} / \mathrm{mL}$, $100 \mu \mathrm{g} / \mathrm{mL}$ were observed $(70.3 \%, 73.8 \%, 70.2 \%, 71.6 \%$, and $76.5 \%$, respectively, vs. positive control) (Fig. 4a).

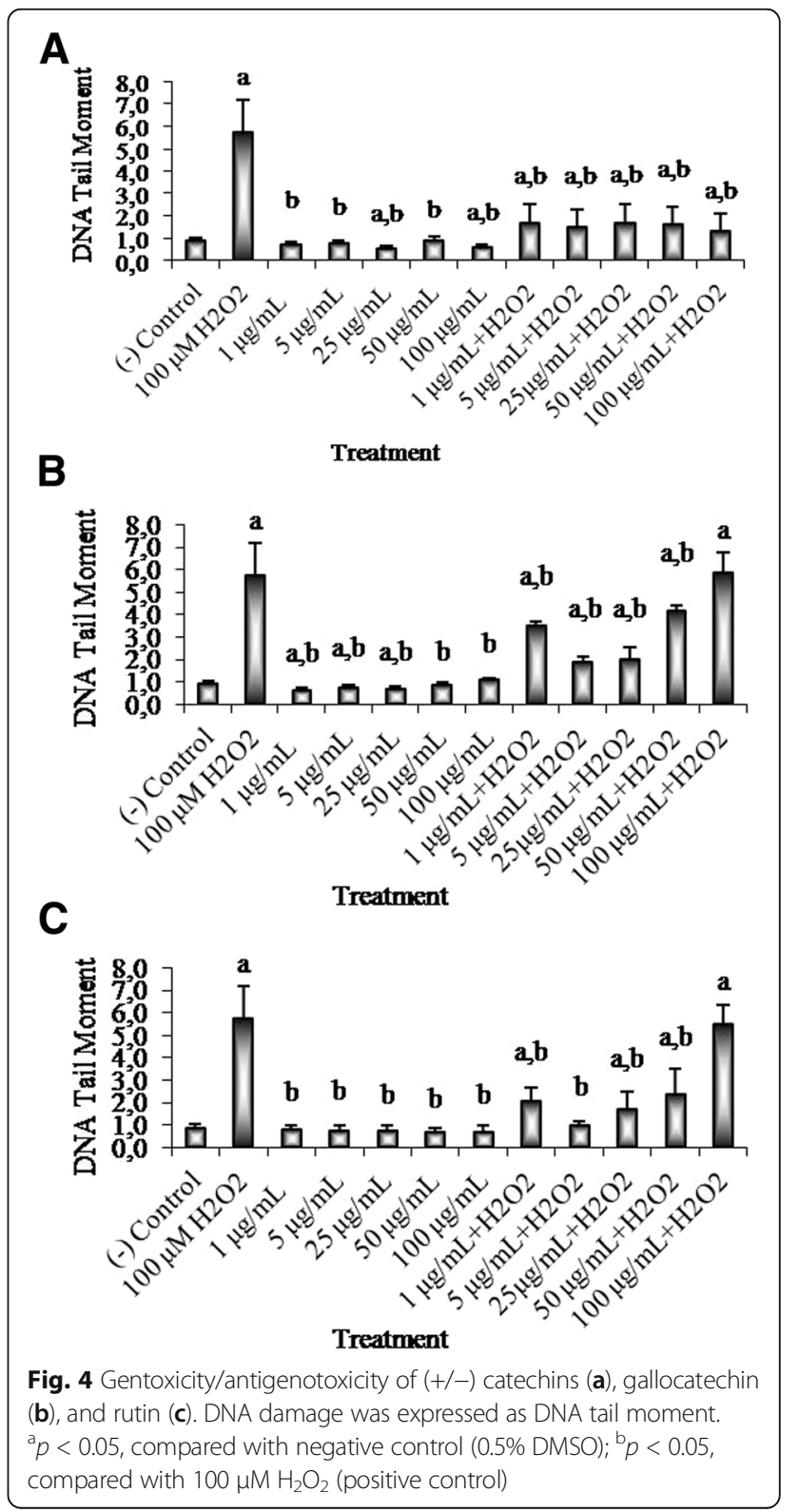



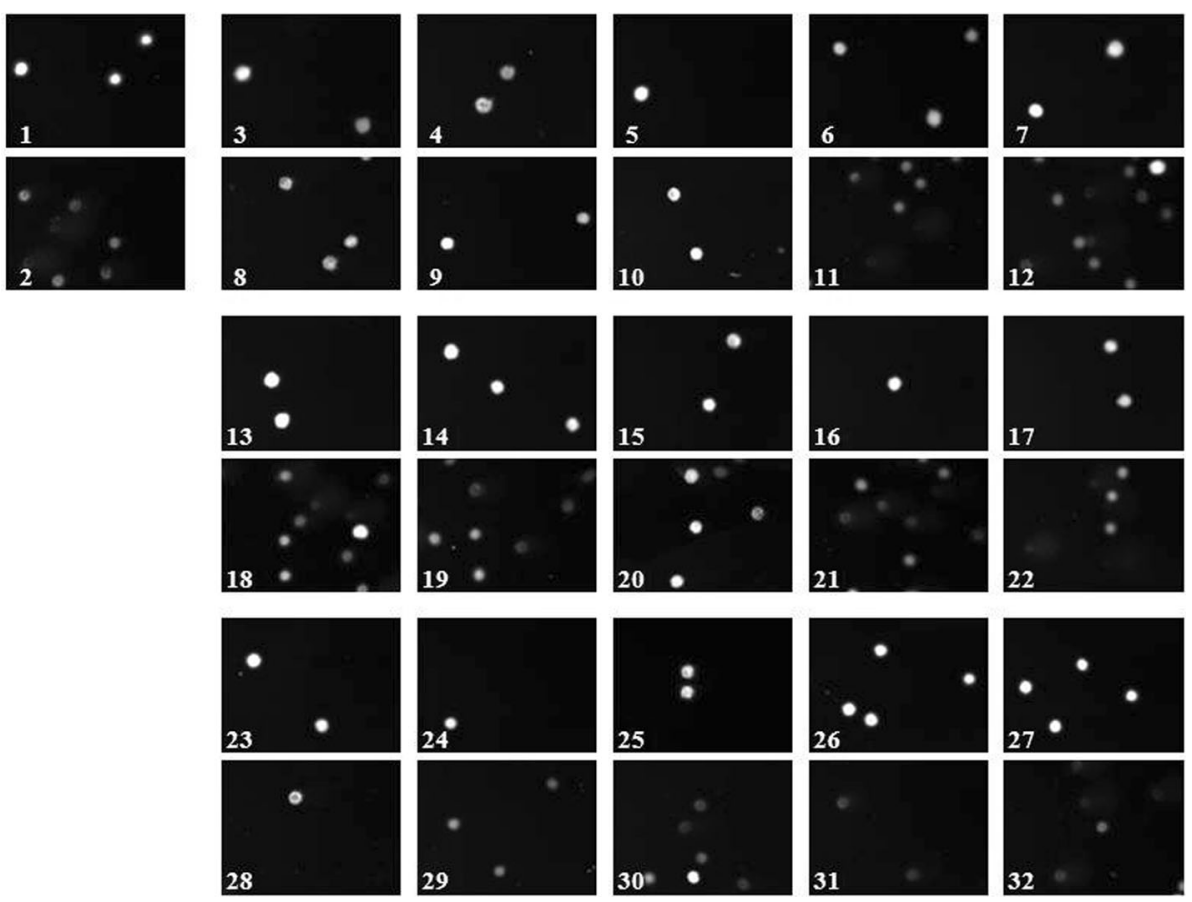

Fig. 5 The images of cells for each treatment in comet assay. (1) Negative control (0.5\% DMSO); (2) positive control (100 $\left.\mu \mathrm{M} \mathrm{H} \mathrm{H}_{2} \mathrm{O}_{2}\right)$. (3) $1 \mu \mathrm{gg} / \mathrm{mL}$ of catechins; (4) $5 \mu \mathrm{g} / \mathrm{mL}$ of catechins; (5) $25 \mu \mathrm{g} / \mathrm{mL}$ of catechins; (6) $50 \mu \mathrm{g} / \mathrm{mL}$ of catechins; (7) $100 \mu \mathrm{g} / \mathrm{mL}$ of catechins; (8) $1 \mu \mathrm{g} / \mathrm{mL}$ of catechins $+\mathrm{H}_{2} \mathrm{O}_{2} ;$ (9) $5 \mu \mathrm{g} / \mathrm{mL}$ of catechins $+\mathrm{H}_{2} \mathrm{O}_{2 i}$ (10) $25 \mu \mathrm{g} / \mathrm{mL}$ of catechins $+\mathrm{H}_{2} \mathrm{O}_{2} ;$ (11) $50 \mu \mathrm{g} / \mathrm{mL}$ of catechins $+\mathrm{H}_{2} \mathrm{O}_{2} ;(12) 100 \mu \mathrm{g} / \mathrm{mL}$ of catechins $+\mathrm{H}_{2} \mathrm{O}_{2}$; (13) $1 \mu \mathrm{g} / \mathrm{mL}$ of gallocatechin; (14) $5 \mu \mathrm{g} / \mathrm{mL}$ of gallocatechin; (15) $25 \mu \mathrm{g} / \mathrm{mL}$ of gallocatechin; (16) $50 \mu \mathrm{g} / \mathrm{mL}$ of gallocatechin; (17) $100 \mu \mathrm{g} / \mathrm{mL}$ of gallocatechin; (18) $1 \mu \mathrm{g} / \mathrm{mL}$ of gallocatechin $+\mathrm{H}_{2} \mathrm{O}_{2} ;$ (19) $5 \mu \mathrm{g} / \mathrm{mL}$ of gallocatechin $+\mathrm{H}_{2} \mathrm{O}_{2} ;(20) 25 \mu \mathrm{g} / \mathrm{mL}$ of gallocatechin $+\mathrm{H}_{2} \mathrm{O}_{2}$; (21) $50 \mu \mathrm{g} / \mathrm{mL}$ of gallocatechin $+\mathrm{H}_{2} \mathrm{O}_{2} ;$ (22) $100 \mu \mathrm{g} / \mathrm{mL}$ of gallocatechin $+\mathrm{H}_{2} \mathrm{O}_{2}$; (23) $1 \mu \mathrm{g} / \mathrm{mL}$ of rutin; (24) $5 \mu \mathrm{g} / \mathrm{mL}$ of rutin; (25) $25 \mu \mathrm{g} / \mathrm{mL}$ of rutin; (26) $50 \mu \mathrm{g} / \mathrm{mL}$ of rutin; (27) $100 \mu \mathrm{g} / \mathrm{mL}$ of rutin; (28) $1 \mu \mathrm{g} / \mathrm{mL}$ of rutin $+\mathrm{H}_{2} \mathrm{O}_{2} ;$ (29) $5 \mu \mathrm{g} / \mathrm{mL}$ of rutin $+\mathrm{H}_{2} \mathrm{O}_{2}$; (30) $25 \mu \mathrm{g} / \mathrm{mL}$ of rutin $+\mathrm{H}_{2} \mathrm{O}_{2} ;(31) 50 \mu \mathrm{g} / \mathrm{mL}$ of rutin $+\mathrm{H}_{2} \mathrm{O}_{2} ;(32) 100 \mu \mathrm{g} / \mathrm{mL}$ of rutin $+\mathrm{H}_{2} \mathrm{O}_{2}$

Similarly, gallocatechin at the concentrations of $1-50 \mu \mathrm{g} / \mathrm{mL}$ was applied to the assay and at the concentrations of $1 \mu \mathrm{g} / \mathrm{mL}, 5 \mu \mathrm{g} / \mathrm{mL}, 25 \mu \mathrm{g} / \mathrm{mL}$, and $50 \mu \mathrm{g} / \mathrm{mL}$ gallocatechin significant decreased oxidative DNA damage $(39.2 \%, 67.3 \%, 65.5 \%$, and $27.7 \%$, for respectively, vs. positive control) $(p<0.05)$ (Fig. 4b).

The same dose dependent responses were observed in rutin and $1 \mu \mathrm{g} / \mathrm{mL}, 5 \mu \mathrm{g} / \mathrm{mL}, 25 \mu \mathrm{g} / \mathrm{mL}$, and $50 \mu \mathrm{g} / \mathrm{mL}$ concentrations of rutin showed decreases in oxidative DNA damage $(64.2 \%, 82.6 \%, 70.3 \%, 58.6 \%$ respectively, vs. positive control) $(p<0.05)$ (Fig. 4c).

In our study, we observed that catechins, gallocatechin, and rutin alone have no genotoxic effects below $100 \mu \mathrm{g} / \mathrm{mL}$. Catechins at the concentrations between $1 \mu \mathrm{g} / \mathrm{mL}$ and $100 \mu \mathrm{g} / \mathrm{mL}$ and gallocatechin and rutin at the concentrations between $1 \mu \mathrm{g} / \mathrm{mL}$ and $50 \mu \mathrm{g} / \mathrm{mL}$ reduced DNA single-strand breaks induced by $\mathrm{H}_{2} \mathrm{O}_{2}$ in V79 cells, indicating that the compounds may have protective effect against oxidative DNA damage. It has been suggested that polyphenols suppress $\mathrm{H}_{2} \mathrm{O}_{2}$-induced DNA damage in the cells [48].
The results were in good correlation with the studies done before. The genotoxic and antigenotoxic activities of catechin in the bark of Hamamelis virginiana L. were investigated in HepG2 cells using comet assay to determine DNA damage. Catechin, hamamelitannin and two proanthocyanidin fractions of the plant extract were found causing slight DNA damage up to concentrations of $166 \mu \mathrm{g} / \mathrm{mL}$. Pretreatment with catechin at a concentration of $18 \mu \mathrm{g} / \mathrm{mL}$ caused a $50 \%$ reduction of the benzo[a]piren induced genotoxicity [49]. Catechins have protective effects on oxidative DNA damage at low concentrations, while it has pro-oxidants effect at high doses. In human lymphocytes, $200 \mu \mathrm{M}$ of EGCG increased oxidative DNA damage [3]. EGCG was also found to induce DNA double-strand breaks in human lung and skin cells above $30 \mu \mathrm{M}$ [50]. In Jurkat T-lymphocytes, EGCG induced and inhibited oxidative DNA damage above $100 \mu \mathrm{M}$ and $10 \mu \mathrm{M}$, respectively [51]. EGCG between $0.01-10 \mu \mathrm{M}$ was found to decrease DNA damage induced by $\mathrm{H}_{2} \mathrm{O}_{2}$ in human lymphocytes [29]. 
In another study, it was reported that rutin pretreatment $(50 \mu \mathrm{M})$ reduced the excessive reactive oxygen species and apoptosis, prevented the increased DNA fragment formation and glutathione depletion, and inhibited the collapse of mitochondrial membrane potentials in human umbilical vein endothelial cells exposed to $\mathrm{H}_{2} \mathrm{O}_{2}$ [52]. The induction of DNA damage in K562 cells after exposition to different concentrations of rutin for $24 \mathrm{~h}$ was studied using comet assay. Rutin alone did not cause significant DNA damage between the concentrations of $50-400 \mu \mathrm{g} / \mathrm{mL}$ and it decreased $\mathrm{H}_{2} \mathrm{O}_{2}$-induced DNA damage at the concentrations of 100,200 , and $400 \mu \mathrm{g} / \mathrm{mL}$ in $\mathrm{K} 562$ cells [46]. Also, at the concentrations of $0.1-200 \mu \mathrm{g} / \mathrm{mL}$ rutin did not induce genotoxicity in HepG2 cells for $2 \mathrm{~h}$ incubation [45].

\section{Conclusions}

The compounds with high polarity were found in the methanolic extract of PS fruits by phytochemical survey. The isolated and identified compounds were $(+)$ and $(-)$ catechins and gallocatechin from ethyl acetate fraction and rutin from n-buthanol phase. The compounds were isolated and purified and elucidated by chromatographic and spectrophotometric methods.

The antigenotoxic studies using comet assay show that the isolated compounds from PS fruits may have protective effect against oxidative DNA damage, which support the ethnopharmacological properties and traditional uses of PS. It seems that PS fruit may be a good resource for clinical research on the treatment of the diseases related to oxidative DNA damage. However, further studies are needed to confirm the activity and clarify the mechanism of action of PS fruits.

\section{Abbreviations}

$\mathrm{CHCl}_{3}$ : Chloroform; COSY: 2D-H $-\mathrm{H}^{1}$ homonuclear correlation; DMSO: Dimethyl sulfoxide; EA: Ethyl acetate; EGCG: (-)-Epigallocatechin-3-gallate; EtBr: Ethidium bromide; FCS: Fetal calf serum; $\mathrm{H}_{2} \mathrm{O}$ : Water; HepG2: Human liver carcinoma cell line; K562 cells: Human myeloid leukemia cell lines; LMA: Low melting point agarose; MEOH: Methanol; MTT: 3-(4,5-dimethylthiazol-2-yl)-2,5-diphenyltetrazolium bromide; $\mathrm{Na}_{2}$-EDTA: Ethylenediamine tetra acetic acid disodium salt dihydrate; $\mathrm{NaCl}$ : Sodium chloride; $\mathrm{NaOH}$ : Sodium hydroxide; NMA: Normal melting point agarose; NMR: Nuclear Magnetic Resonance; PBS: Phosphate buffered saline; PS: Paliurus spina-christi Mill.fruits; ROS: Reactive oxygen species; TLC: Thin layer chromatography; V79 cells: Chinese hamster lung fibroblast cell lines

\section{Acknowledgements}

$M Z, N B, A A B, S A$ are strongly acknowledged for their kind supervisions, expert guidance and generous facilitations of all necessary materials and equipments. We would like to thank our department chair who provided only general support.

\section{Funding}

Not applicable.

\section{Availability of data and materials}

The authors accept that the raw data and materials described in our study are freely available to any scientist wishing to use them for non-commercial purposes, as long as this does not breach participant confidentiality.

\section{Authors' contributions}

$M Z^{1}, N^{\prime} G^{3}, S^{2}$, provide help in experimentation, data collection and analysis. $S A^{2}$ $N B^{2}, A A B^{4}$, provide the necessary facilities and edited the manuscript. All authors read and approved the final manuscript. The authors alone are responsible for the content of this manuscript.

\section{Authors' information}

Not applicable.

\section{Competing interests}

Financial competing interests.

This information is not relevant for our study. The author(s) declare that they have no financial competing interests.

Non-financial competing interests.

This information is not relevant for our study. The author(s) declare that they have no non-financial competing interests.

\section{Consent for publication}

Not applicable.

Ethics approval and consent to participate

Not applicable.

\section{Publisher's Note}

Springer Nature remains neutral with regard to jurisdictional claims in published maps and institutional affiliations.

\section{Author details}

${ }^{1}$ Department of Pharmacognosy, Faculty of Pharmacy, Bülent Ecevit University, 67100 Zonguldak, Turkey. ${ }^{2}$ Department of Pharmaceutical Toxicology, Faculty of Pharmacy, Hacettepe University, 06100 Ankara, Turkey. ${ }^{3}$ Republic of Turkey Social Security Institution, 06520 Ankara, Turkey.

${ }^{4}$ Department of Pharmacognosy, Faculty of Pharmacy, Hacettepe University, 06100 Ankara, Turkey.

Received: 22 September 2016 Accepted: 8 April 2017

Published online: 26 April 2017

\section{References}

1. Rao BN. Bioactive phytochemicals in Indian foods and their potential in health promotion and disease prevention. Asia Pac J Clin Nutr. 2003;12(1):9-22.

2. Habauzit $V$, Morand C. Evidence for a protective effect of polyphenolscontaining foods on cardiovascular health: an update for clinicians. Ther Adv Chronic Dis. 2012;3(2):87-106.

3. Sutherland BA, Rahman RM, Appleton I. Mechanisms of action of green tea catechins, with a focus on ischemia- induced neurodegeneration. J Nutr Biochem. 2006;17(5):291-306.

4. Zaveri NT. Green tea and its polyphenolic catechins: medicinal uses in cancer and noncancer applications. Life Sci. 2006;78(18):2073-80.

5. Cao G, Sofic E, Prior RL. Antioxidant and prooxidant behavior of flavonoids: structure-activity relationships. Free Radic Biol Med. 1997;22(5):749-60.

6. Brantner AH, Males Z. Quality assessment of Paliurus spina-christi extracts. J Ethnopharmacol. 1999;66(2):175-9.

7. Brantner AH, Males Z. Investigations on the flavonoid glycosides of Paliurus spina-christi. Planta Med. 1990;56(6):582-3.

8. Güner ND. Paliurus spina-christi Mill. Ankara, Turkey: Üzerinde Farmakognozik Araştırmalar, MSc, Hacettepe University, Graduate School of Health Sciences; 2005.

9. Brantner A, Males Z, Pepeljnjak S, Antolić A. Antimicrobial activity of Paliurus spina-christi Mill.(Christ's thorn). J Ethnopharmacol. 1996;52(2):119-22.

10. Deliorman Orhan D, Özçelik B, Hoşbaş S, Vural M. Assessment of antioxidant, antibacterial, antimycobacterial, and antifungal activities of some plants used as folk remedies in Turkey against dermatophytes and yeast-like fungi. Turk J Biol. 2012;36(6):672-86.

11. El Rabe HA, Attia ES, Al-Seeni MN, Al-Sieni Al, Ibrahim IH, Meerasahib MF, Shaikh-Omer AM, Abuelgassim AO. The hypolipidemic and antioxidant activity of Christ's thorn (Ziziphus Spina- Christi) leaves powder in hypercholesterolemic male rats. Life Sci J. 2014;11(10):1010-21.

12. Kemertelidze EP. Dalakishvili Ts. M, Gusakova SD, Shalashvili KG, Khatiashvili NS, Bitadze MA, Gogilashvili LM, Bereznyakova Al. Chemical composition 
and pharmacological activity of the fruits of Paliurus spina-christi Mill. Pharmaceut Chem J. 1999;33(11):591-4.

13. Akbay $P$, Başaran AA, Ündeğer Ü, Başaran N. In vitro immunomodulatory activity of flavonoid glycosides from Urtica dioica L. Phytother Res. 2003;17:34-7.

14. Aydın S, Başaran AA, Başaran N. The effects of thyme volatiles on the heterocylic aromatic amine IQ and the mitomycin C induced DNA damage. Mutat Res. 2005;581:43-53.

15. Aydın S, Başaran AA, Başaran N. Modulating effects of Thyme and its major ingredients on oxidative DNA damage in human lymphocytes. J Agric Food Chem. 2005;3(4):1299-305.

16. Ostling O, Johanson KJ. Microelectrophoretic study of radiation-induced DNA damages in individual mammalian cells. Biochem Biophys Res Commun. 1984:123(1):291-8.

17. Singh NP, McCoy MT, Tice RR, Schneider EL. A simple technique for quantitation of low levels of DNA damage in individual cells. Exp Cell Res. 1988;175(1):184-91.

18. Collins AR, Dobson VL, Dusinka M, Kennedy G, Stetina R. The comet assay: what can it really tell us? Mutat Res. 1997:375:183-93.

19. Olive PL. DNA damage and repair in individual cells: applications of the comet assay in radiobiology. Int J Radiat Biol. 1999;75:395-405.

20. Anderson D, Dobrzynska MM, Başaran N, Başaran AA, Yu T-W. Flavonoids modulate comet assay responses to Food mutagens in human lymphocytes and sperm. Mutat Res. 1998:402:269-77.

21. Ündeğer Ü, Aydın S, Başaran AA, Başaran N. The modulating effects of quercetin and rutin on the mitomycin $C$ induced DNA strand breakage. Toxicol Lett. 2004;151:143-9.

22. Ündeğer Ü, Başaran A, Degen GH, Başaran N. Antioxidant activities of major thyme ingredients and lack of (Oxidative) DNA damage in V79 Chinese Hamster lung fibroblast cells at low levels of carvacrol and thymol. Food Chem Toxicology. 2009;47:2037-43.

23. Tokaç M, Taner G, Aydın S, Özkardeş AB, Dündar HZ, Taşııpınar MY, Arıkök AT, Kılıç M, Başaran AA, Basaran N. Protective effects of curcumin on oxidative stress parameters and DNA damage in the livers and kidneys of rats with biliary obstruction. Food Chem Toxicol. 2013;61:28-35.

24. Taner G, Aydın S, Aytaç Z, Başaran AA, Başaran N. Assessment of the cytotoxic, genotoxic and antigenotoxic potential of pycnogenol in in vitro mammalian cells. Food Chem Toxicol. 2013;61:203-8.

25. Aydın S, Bacanlı M, Taner G, Sahin T, Başaran AA, Başaran N. Protective effects of resveratrol on sepsis-induced DNA damage in the lymphocytes of rats. Hum Exp Toxicol. 2013;32(10):1048-57.

26. Aydın S, Tokaç M, Taner G, Arıkök AT, Dündar HZ, Özkardeş AB, Taşlıpına MY, Kılıç M, Başaran AA, Başaran N. Antioxidant and antigenotoxic effects of lycopene in obstructive jaundice. J Surg Res. 2013;182(2):285-95.

27. Taner G, Aydın S, Bacanlı M, Sarıgöl Z, Şahin T, Başaran AA, Başaran N. Modulating effects of Pycnogeno ${ }^{\circledR}$ on oxidative stress and DNA damage induced by sepsis. Phytoter Res. 2014;28(11):1692-700.

28. Bacanlı M, Aydın S, Taner G, Göktaş HG, Şahin TT, Başaran AA, Başaran N. The protective role of ferulic acid on sepsis-induced oxidative damage in Wistar albino rats. Environ Toxicol Pharmacol. 2014;38(3):774-82.

29. Aydın S, Tokaç D, Başaran N, Başaran AA. Effect of epigallocatechin gallate on oxidative DNA damage in human lymphocytes. Turk J Pharm Sci. 2015; 12(1):19-28

30. Tokaç M, Aydın S, Taner G, Özkardeş AB, Taşlıpınar MY, Doğan M, Dündar $H Z$, Kılıç M, Başaran AA, Başaran N. Hepatoprotective and antioxidant effects of Lycopene in acute Cholestasis. Turk J Med Sci. 2015:45(4):857-64

31. Bacanlı M, Başaran AA, Başaran N. The antioxidant and antigenotoxic properties of citrus phenolics limonene and naringin. Food Chem Toxicol. 2015;81:160-70

32. Bacanlı M, Aydın S, Taner G, Göktaş H.G, Şahin T.T, Başaran A.A, Başaran N. Does Rosmarinic acid treatment have protective role Aganist sepsis-induced oxidative damage in Wistar albino rats. Hum Environ Toxicol. 2016; 35(8): 877-886.

33. Bacanlı M, Başaran A.A, Başaran N. The antioxidant, cytotoxic and antigenotoxic effects of galangin, puerarin and ursolic acid in mammalian cells. Drug Chem Toxicol. 2016; (doi: 10.1080/01480545.2016.1209680)

34. Mosmann T. Rapid colorimetric assay for cellular growth and survival: application to proliferation and cytotoxicity assays. J Immunol Methods. 1983:65(1-2):55-63.

35. Denizot F, Lang R. Rapid colorimetric assay for cell growth and survival. Modifications to the tetrazolium dye procedure giving improved sensitivity and reliability. J Immunol Methods. 1986;89(2):271-7.
36. Tice RR, Agurell E, Anderson D, Burlinson B, Hartmann A, Kobayashi H, Miyamae Y, Rojas E, Ryu JC, Sasaki YF. Single cell gel/comet assay: guidelines for in vitro and in vivo genetic toxicology testing. Environ Mol Mutagen. 2000;35(3):206-21.

37. Foo LY, Karchesy JJ. Procyanidin dimers and trimers from Douglas fir inner bark. Phytochemistry. 1989;28(6):1743-7.

38. Harborne JB, Mabry TJ. The flavonoids: Advences in research. London: Chapman and Hall; 1982

39. Agrawal PK. NMR spectroscopy in the structural elucidation of oligosaccharide and glycosides. Phytochemistry. 1992;31(10):3307-30.

40. Kustrak D, Males Z, Pitaveric I. Determination of the content of total polyphenols and tannins of Christ's thorn (Paliurus spina-christi Mill.). Farm Glas. 1993:49(4):105-9.

41. Males Z, Medic-Saric M, Kustrak D. Application of numerical methods in the investigation of the flavonoids of Christ, $\mathrm{s}$ thorn (Paliurus spina-christi Mill.). Acta Pharma. 1994;44(2):183-91.

42. Beck M, Haberlein H. Flavonol glycosides from Eschscholtzia californica. Phytochemistry. 1999;50(2):329-32.

43. Jain P, Kumar N, Josyula VR, Jagani HV, Udupa N, Mallikarjuna Rao C Vasanth Raj P. A study on the role of (+)-catechin in suppression of HepG2 proliferation via caspase dependent pathway and enhancement of its in vitro and in vivo cytotoxic potential through liposomal formulation. Eur J Pharm Sci. 2013; 50(3*4):353-65

44. Yoo KM, Hwang IK, Moon B. Comparative flavonoids contents of selected herbs and associations of their radical scavenging activity with antiproliferative actions in V79-4 cells. J Food Sci. 2009;74(6):C419-25.

45. Araújo KC, de M B Costa EM, Pazini F, Valadares MC, de Oliveira V. Bioconversion of quercetin and rutin and the cytotoxicity activities of thetransformed products. Food Chem Toxicol. 2013;51:93-6.

46. Rhouma GB, Chebil L, Mustapha N, Krifa M, Ghedira K, Ghoul M, ChékirGhédira L. Cytotoxic, genotoxic and antigenotoxic potencies of oligorutins. Hum Exp Toxicol. 2013;32(8):881-9.

47. Barcelos GR, Grotto D, Angeli JP, Serpeloni JM, Rocha BA, Bastos JK, Barbosa Jr F. Evaluation of antigenotoxic effects of plant flavonoids quercetin and rutin on HepG2 cells. Phytother Res. 2011;25(9):1381-8.

48. Nakayama T. Suppression of hydroperoxide-induced cytotoxicity by polyphenols. Cancer Res. 1994:54(7 Suppl):1991-3.

49. Dauer A, Hensel A, Lhoste E, Knasmüller S, Mersch-Sundermann V. Genotoxic and antigenotoxic effects of catechin and tannins from the bark of Hamamelis virginiana $\mathrm{L}$. in metabolically competent, human hepatoma cells (Hep G2) using single cell gel electrophoresis. Phytochemistry. 2003; 63(2):199-207.

50. Lu LY, Ou N, Lu QB. Antioxidant induced DNA damage, cell death and mutagenicity in human lung and skin normal cells. Sci Rep. 2013:3:3169.

51. Johnson MK, Loo G. Effects of epigallocatechin gallate and quercetin on oxidative damage to cellular DNA. Mutat Res. 2000:459(3):211-8.

52. Gong G, Qin Y, Huang W, Zhou S, Yang X, Li D. Rutin inhibits hydrogen peroxide-induced apoptosis through regulating reactive oxygen species mediated mitochondrial dysfunction pathway in human umbilical vein endothelial cells. Eur J Pharmacol. 2010:628(1-3):27-35.

\section{Submit your next manuscript to BioMed Central and we will help you at every step:}

- We accept pre-submission inquiries

- Our selector tool helps you to find the most relevant journal

- We provide round the clock customer support

- Convenient online submission

- Thorough peer review

- Inclusion in PubMed and all major indexing services

- Maximum visibility for your research

Submit your manuscript at www.biomedcentral.com/submit 